Metals and Ceramics Division

HIGH-TEMPERATURE THERMAL STORAGE SYSTEMS FOR ADVANCED SOLAR RECEIVERS MATERIALS SELECTION

D. F. Wilson

J. H. DeVan

M. Howell

Date Published: September 1990

NOTICE: This document contains information of a preliminary nature. It is subject to revision or correction and therefore does not represent a final report.

Research supported by the NASA Lewis Research Center, Advanced Solar Dynamic Program

\footnotetext{
Prepared by the OAK RIDGE NATIONAL LABORATORY

Oak Ridge, Tennessee 37831-6285 operated by MARTIN MARIETTA ENERGY SYSTEMS, INC. for the

U.S. DEPARTMENT OF ENERGY under contract DE-AC05-84OP21400
} 


\section{CONTENTS}

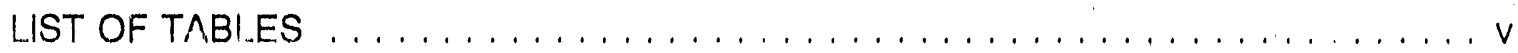

LIST OF FIGURES $\ldots \ldots \ldots \ldots \ldots \ldots \ldots \ldots \ldots \ldots \ldots \ldots \ldots$

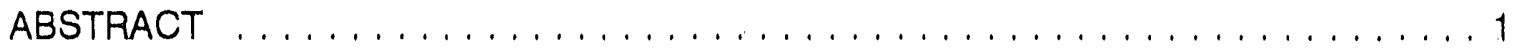

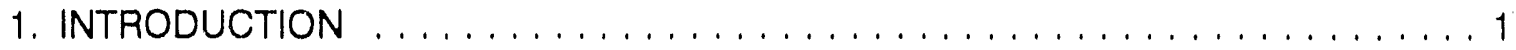

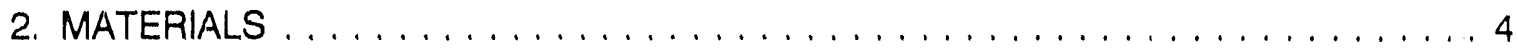

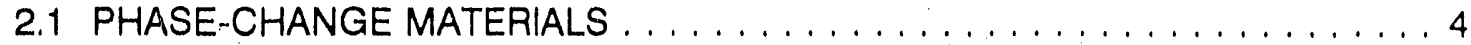

2.2 CONTAINMENT MATERIALS $\ldots \ldots \ldots \ldots \ldots \ldots \ldots \ldots \ldots \ldots$

3. EXPERIMENTAL PROCEDURES $\ldots \ldots \ldots \ldots \ldots \ldots \ldots \ldots \ldots \ldots \ldots \ldots$

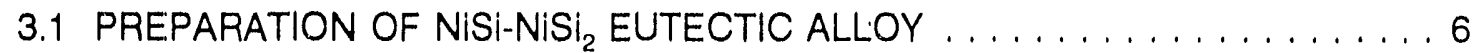

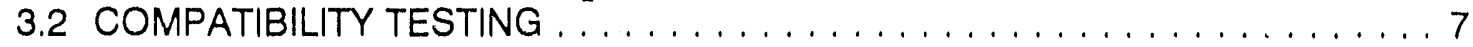

4. RESULTS AND DISCUSSION $\ldots \ldots \ldots \ldots \ldots \ldots \ldots \ldots \ldots \ldots \ldots \ldots$

4.1 CHARACTERIZATION OF NiSi-NiSi ${ }_{2}$ EUTECTIC ALLOY . . . . . . . . . . . 9

4.2 COMPATIBILITY STUDIES WITH NISi-NiSi ${ }_{2}$ EUTTECTIC ALLOY . . . . . . . 13

4.3 COMPATIBILITY STUDIES WITH GERMANIUM $\ldots \ldots \ldots \ldots \ldots \ldots$

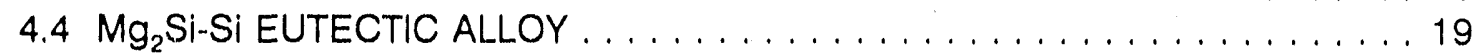

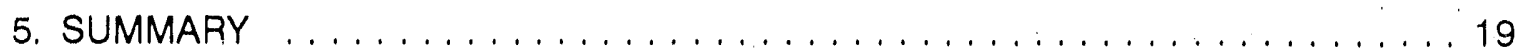

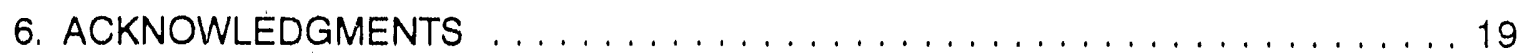

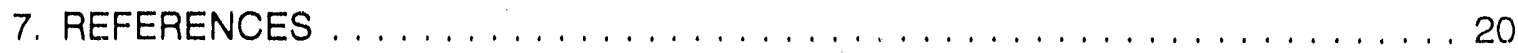




\section{LIST OF TABLES}

Table 1. Reference storage system for

Braytun Cycle Solar Dynamic systems . . . . . . . . . . . . . . 2

Table 2. Salt PCMs for Stirling engines $\ldots \ldots \ldots \ldots \ldots \ldots \ldots \ldots$

Table 3. Silicon-based alloys for thermal energy storage $\ldots \ldots \ldots \ldots \ldots \ldots \ldots$

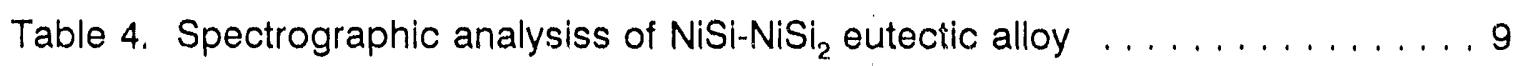




\section{LIST OF FIGURES}

Fig. 1. Thermal expansion coefficients of germanium and selected containment materials

Fig. 2. Test assembly consisting of an alumina crucible and cap encapsulated in quartz

Fig. 3. Optical micrograph of NiSi-NiSi ${ }_{2}$ specimen SD4, etched with $50 \% \mathrm{HCl} / 10 \%$ Gly $/ 10 \% \mathrm{HNO}_{3}$

Fig. 4. Optical micrograph of NiSi-NiSi ${ }_{2}$ specimen SD4, etched with $50 \% \mathrm{HCl} / 10 \%$ Gly $/ 10 \% \mathrm{HNO}_{3}$. As compared to Fig. 3, there is a significantly smaller quantity of the excess phase $\mathrm{NiSi}_{2}$

Fig. 5. Segment of $X$-ray diffraction pattern of $\mathrm{NiSi}-\mathrm{NiSl} \mathrm{I}_{2}$ eutectic, using copper $k$-alpha radiation of wavelength $1.54059 \AA$

Fig. 6. Optical micrograph of $\mathrm{NiSi}-\mathrm{NiSl}_{2}$ reacted at $1289 \mathrm{~K}$ for $168 \mathrm{~h}$ in a crucible of pyrolytic carbon of $0.005 \mathrm{~cm}(0.0020 \mathrm{in}$.) thickness on graphite. Magnification is $400 \mathrm{X}$

Fig. 7. SEM micrograph of a portion of the pyrolytic carbon on graphite near the fracture site of the crucible. This surface was in contact with molten $\mathrm{NiSi}-\mathrm{NiSi}_{2}$ at temperature

Fig. 8. Optical micrograph of CVD SiC reacted at $1289 \mathrm{~K}$ for $186 \mathrm{~h}$, showing a negative meniscus and a small wetted area

Fig. 9. Optical photograph showing CVD boron nitride contained within $\mathrm{NiSi}-\mathrm{NiSi}_{2}$ and germanium. Note that one crucible is shattered

Fig. 10. Optical micrography of the NiSi-NiSi $/$ /CVD

boron nitride interface. There are no indications of interactions 18 


\title{
HIGH-TEMPERATURE THERMAL STORAGE SYSTEMS \\ FOR ADVANCED SOLAR RECEIVERS \\ MATERIALS SELECTION
}

D. F. Wilson, J. H. DeVan, and M. Howell

\begin{abstract}
Advanced space power systems that use solar energy and Brayton or Stirling heat engines require thermal energy storage (TES) systems to operate continuously through periods of shade. The receiver storage units, key elements in both Brayton and Stirling systems, are designed to use the latent heat of fusion of phase-change materials (PCMs). The power systems under current consideration for near-future National Aeronautics and Space Administration space missions require working fluid temperatures in the 1100 to $1400 \mathrm{~K}$ range. The PCMs under current investigation that have liquidus temperatures within this range are the fluoride family of salts. However, these salts have low thermal conductivity, which causes large temperature gradients in the storage systems. Improvements can be obtained, however, with the use of thermal conductivity enhancements or metallic PCMs. In fact, if suitable containment materials can be found, the use of metallic PCMs would virtually eliminate the orbit associated temperature variations in TES systems.

The high thermal conductivity and generally low volume change on melting of germanium and alloys based on silicon make them attractive for storage of thermal energy in space power systems. An approach to solving the containment problem, involving both chemical and physical compatibility, preparation of $\mathrm{NiSi} / \mathrm{NiSi}_{2}$, and initial results for containment of germanium and $\mathrm{NiSi} / \mathrm{NiSi}_{2}$, are presented.
\end{abstract}

\section{INTRODUCTION}

Thermal energy storage (TES) systems are required for continuous operation of advanced space power systems that use solar energy and Brayton or Stirling heat engines. Storage systems have been designed to use the latent heat of fusion of metals or salts. Energy is stored during the heating and melting of a phase-change material (PCM) in the sunlit portion oi the orbit. The PCM cools and freezes, thereby releasing heat to the engine, during the eclipse period of the orbit. In a latent-heat system, heat is theoretically absorbed and liberated at a constant temperature. However, in actuality, a constant temperature is difficult to achieve because the solid phase of the PCM (lower thermal conductivity) forms on the heat-transfer surfaces. ${ }^{1}$ The current reference PCM thermal energy storage systern for the Brayton Cycle is based on LiF-CaF eutectic contained in Haynes-188 canisiers. Characteristics of this system are listed in Table 1. Possible salt PCMs for the Stirling engines are listed in Table 2. 
Table 1. Reference storage system for Brayton Cycle Solar Dynamic systems

\begin{tabular}{|c|c|}
\hline \multicolumn{2}{|l|}{$\mathrm{PCM}$} \\
\hline Materlal & $\mathrm{LIF} 20 \mathrm{CaF}_{2}$ \\
\hline $\begin{array}{l}\text { Melt temperature } \\
\text { Heat of fusion }\end{array}$ & $1040 \mathrm{~K}$ \\
\hline Speclfic & $815 \mathrm{~kJ} / \mathrm{kg}$ \\
\hline Volumetric & $1.71 \mathrm{~kJ} / \mathrm{cm}^{3}$ \\
\hline Thermal conductivity & \\
\hline Solid & $4.0 \mathrm{~W} / \mathrm{m} \cdot \mathrm{K}$ \\
\hline Liquid & $1.6 \mathrm{~W} / \mathrm{m} \cdot \mathrm{K}$ \\
\hline Density, liquid & $2.1 \mathrm{~g} / \mathrm{cm}^{3}$ \\
\hline Vold formation & $22 \% \Delta V / N_{1}$ \\
\hline \multicolumn{2}{|l|}{ Container } \\
\hline Material & Haynes-188 \\
\hline Maximum temperature & $\sim 1100 \mathrm{~K}$ \\
\hline \multicolumn{2}{|l|}{ System } \\
\hline $\begin{array}{l}\text { Specific heat storage }{ }^{a} \text { (maximum) } \\
\text { Volumetric heat storage (maximum) }\end{array}$ & $\begin{array}{l}300 \mathrm{~kJ} / \mathrm{kg} \\
1.3 \mathrm{~kJ} / \mathrm{cm}^{3}\end{array}$ \\
\hline
\end{tabular}

a Estimated using the dimensions of a heat storage canister proposed for a space station system, assuming complete melting and freezing of the PCM in each cycle.

Source: Wichner, R.P.; Schmidt, M.A.; and DeVan, J.H., Oak Ridge National Laboraiory, "Improved Performance Options for Solar Dynamic Heat Storage Systems," personal communication to NASA Lewis Research Center, Cleveland, Jhio, 1988. 
Table 2. Salt PCMs for Stirling engines

\begin{tabular}{|c|c|c|}
\hline & $\begin{array}{l}T_{m} \\
(K)\end{array}$ & $\underset{(k J / k g}{\Delta h}$ \\
\hline \multicolumn{3}{|c|}{$I_{m}$ in optimum range $(1100 \mathrm{~K}-1200 \mathrm{~K})$} \\
\hline $\mathrm{NaF}-24 \mathrm{MgF}_{2}$ & 1103 & $\sim 655$ \\
\hline LiF & 1120 & 1087 \\
\hline $\mathrm{NaF}-27 \mathrm{CaF}_{2}-36 \mathrm{MgF}_{2}$ & 1178 & $\sim 520$ \\
\hline \multicolumn{3}{|c|}{$I_{m}$ above optimum range $(1200 \mathrm{~K}-1300 \mathrm{~K})$} \\
\hline $\begin{array}{l}\mathrm{MgF}_{2}-43 \mathrm{CaF}_{2} \\
\mathrm{NaF}_{-36 \mathrm{MaF}_{2}}\end{array}$ & $\begin{array}{l}1227 \\
1260\end{array}$ & \\
\hline $\mathrm{NaF}$ & 1268 & 789 \\
\hline $\mathrm{NaMgF}_{3}$ (line compound) & 1303 & 711 \\
\hline \multicolumn{3}{|c|}{$I_{m}$ below optimum range $(1000 \mathrm{~K}-1100 \mathrm{~K})$} \\
\hline $\mathrm{LiF}-2 \mathrm{O} \mathrm{CaF}{ }_{2}$ & 1040 & 815 \\
\hline $\mathrm{NaF}-32 \mathrm{CaF}_{2}$ & 1083 & $\sim 540$ \\
\hline
\end{tabular}

Source: Wichner, R.P.; Schmidt, M.A.; and DeVan, J.H., Oak Ridge National Laboratory, "Improved Performance Options for Solar Dynamic Heat Storage Systems," personal communication to NASA Lewis Research Center, Cleveland, Ohio, 1988.

Several parameters are imporiant in the choice of a $\mathrm{PCM}^{2}$ The melting temperature of the PCM musi be higher than the operating temperature of the chosen thermodynamic heat engine. The heat of fusion and density determine the mass and volume of PCM required to store a given amount of energy. The volume charige on fusion (void formation) and thermal conductivity affect heat transfer and, thus, container design. Solomon ${ }^{3}$ has demonstrated the dependence of the overall performance of the TES system on latent heat and thermal conductivity. He reported that doubling the latent heat of fusion of the PCM not only reduces the mass of the PCM required for energy storage by $\sim 50 \%$, but also reduces the percent variation (charging/discharging) in the energy stored. Also, he showed that doubling the thermal conductivity reduces the large oscillations in temperature of the outlet gas temperature by $\sim 30 \%$.

In general, salts and their eutectics have low thermal conductivities. However, it is desired that only a small temperature drop occur across the PCM during thermal discharge to minimize variations in the temperature of the outlet gas into the power system. Therefore, large heat-exchange surface areas are required to minimize the temperature gradients in the energy storage and removal system. In addition, these salts undergo volume changes (as much as $40 \%)^{1}$ during their phase changes, ana voids are generated. These voids will likely have an adverse effect on heat transfer into and out of the TES container. Also, high stresses may occur if the expanding liquid phase cannot communicate with the voids. 
Several means for improving the performance of thermal energy systems have been considered by Wichner et al. ${ }^{\star}$ These include

1. higher heat storage temperature, thus increasing the thermodynamic cycle efficiency;

2. higher latent heat, thus reducing the total mass of the receiver;

3. higher thermal conductance, thus allowing more of the PCM to melt in a given time with a given temperature gradient; and

4. reducing void volume, thus increasing heat transfer and reducing thermal stresses.

All of : iese approaches can be implemented using metallic PCMs.

vivichner et al, considered (1) congruently melting line compounds or elements in which a single phase is in equilibrium with a single liquid phase at its melting point; (2) eutectics, in which two solid phases are in equilibrium with a single liquid phase at the liquidus temperature; and (3) solld solutions, in which a single solid phase melts incongruently between the solidus and liquidus temperature. These types of materials are regarded as ideal because they in theory would release energy isothermally on solidification. Table 3 lists the materials suggested by Wichner et al. as candidate PCMs. The materials are divided into four groups, and within each group the inembers are expected to behavior similarly. However, many of the parameters of interest such as latent heat of fusion, thermal conductivity and expansion, volume change on transformation of state, density, liquidus temperature, and amount of undercooling are not known for the silicon-based alloys.

Low-density metals are of particular interest as possible advanced heat-storage media isecause of their high thermal conductivity and generally low volume change on melting as compared to salts. However, the candidate metals are generally reactive with commonly used containment materials; as a result. the range of suitable materials is narrowed to ceramics with low connected porosity and small pore sizes. The compatibility problem for these TES systems was approached from a hierarchy that considered chemical reactivity; solubility; and physical compatibility, especially thermal expansion mismatch.

\section{MATERIALS}

\subsection{PHASE-CHANGE MATERIALS}

Based on the analysis of Wichner et al., three candidate PCM materlals were chosen for the initial screening work. These PCMs were germanium, a NiSi-NiSi ${ }_{2}$ eutectic alloy (Group VIIIA - Si systems), and a $\mathrm{Mg}_{2} \mathrm{Si}$-Si eutectic alloy (Group IIA - Si systems).

\footnotetext{
*Wichner, R.P.; Schmidt, M.A.; and DeVan, J.H., Oak Ridge National Laboratory, "Improved Performance Options for Solar Dynamic Heat Storage Systems," personal communications to NASA Lewis Research Center, Cleveland, Ohio,1988.
} 
Table 3. Silicon-based alloys for thermal energy storage

\begin{tabular}{|c|c|c|c|}
\hline & & $\begin{array}{l}T_{m} \\
(K)\end{array}$ & $\underset{(\mathrm{kJ} / \mathrm{kg})}{\Delta H_{\mathrm{m}}}$ \\
\hline \multicolumn{4}{|c|}{ Group VIII/. - Si systems } \\
\hline $\begin{array}{l}\text { PdSI-Si } \\
\text { PdSi }\end{array}$ & $\begin{array}{l}\text { Eutectic } \\
\text { Compound }\end{array}$ & $\begin{array}{l}1143 \\
1363\end{array}$ & $\begin{array}{l}480 \\
520\end{array}$ \\
\hline $\begin{array}{l}\mathrm{NiSl}+\mathrm{NiSl}_{2} \\
\mathrm{NiSl}\end{array}$ & $\begin{array}{l}\text { Eutectic } \\
\text { Compound }\end{array}$ & $\begin{array}{l}1239 \\
1265\end{array}$ & $\begin{array}{l}640 \\
750\end{array}$ \\
\hline $\begin{array}{l}\mathrm{Fe}_{2} \mathrm{SI}_{5}-\mathrm{Si} \\
\mathrm{FeSl}_{2} \mathrm{Fe}_{2} \mathrm{Si}_{5} \\
\mathrm{Fe}_{2} \mathrm{SI}_{5}\end{array}$ & $\begin{array}{l}\text { Eutectic } \\
\text { Eutectic } \\
\text { Compound }\end{array}$ & $\begin{array}{l}1480 \\
1485 \\
1493\end{array}$ & $\begin{array}{r}1000 \\
900 \\
1180\end{array}$ \\
\hline \multicolumn{4}{|c|}{ Group VII - Si systems } \\
\hline $\begin{array}{l}\mathrm{Mn}_{11} \cdot S I_{19} \\
\operatorname{ReSI}_{2}-S i\end{array}$ & $\begin{array}{l}\text { Compound } \\
\text { Eutectic }\end{array}$ & $\begin{array}{l}1418 \\
1398\end{array}$ & $\begin{array}{r}1130 \\
948\end{array}$ \\
\hline \multicolumn{4}{|c|}{ Group IIA - Si systems } \\
\hline $\begin{array}{l}\mathrm{Mg}_{2} \mathrm{Si}-\mathrm{Si} \\
\mathrm{Mg}_{2} \mathrm{Si}\end{array}$ & $\begin{array}{l}\text { Eutectic } \\
\text { Compound }\end{array}$ & $\begin{array}{l}1219 \\
1358\end{array}$ & $\begin{array}{r}800-1000 \\
1100\end{array}$ \\
\hline $\mathrm{CaSi}_{2}-\mathrm{Si}$ & Eutectia & 1253 & 1100 \\
\hline $\begin{array}{l}\mathrm{SrSi}_{2}-\mathrm{Si} \\
\mathrm{SrSi}_{-} \mathrm{SrSi}_{2} \\
\mathrm{SrSi}_{2}\end{array}$ & $\begin{array}{l}\text { Eutectic } \\
\text { Eutectic } \\
\text { Compound }\end{array}$ & $\begin{array}{l}1273 \\
1317 \\
1423\end{array}$ & $\begin{array}{l}870 \\
660 \\
850\end{array}$ \\
\hline $\mathrm{BaSi}_{2}$ & Compound & 1453 & 630 \\
\hline \multicolumn{4}{|c|}{ Ge-Si Solution systems } \\
\hline $\begin{array}{l}\mathrm{Ge} \\
\mathrm{Ge}-0.2 S i \\
\mathrm{Ge}-0.4 S i \\
\mathrm{Ge}-0.6 \mathrm{Si} \\
\mathrm{Ge}-0.8 \mathrm{Si} \\
\mathrm{Si}\end{array}$ & $\begin{array}{l}\text { Element } \\
\text { Solution } \\
\text { Solution } \\
\text { Solution } \\
\text { Solution } \\
\text { Element }\end{array}$ & $\begin{array}{r}1211 \\
1270-1410 \\
1340-1510 \\
1430-1580 \\
1560-1640 \\
1687\end{array}$ & $\begin{array}{r}510 \\
650 \\
830 \\
1130 \\
1330 \\
1800\end{array}$ \\
\hline
\end{tabular}


Germanlum is commerclally avallable. As will be discussed later, the NISI-NISI ${ }_{2}$ eutectic can be readlly made, but preparation of $\mathrm{Mg}_{2} S \mathrm{~S}-\mathrm{Si}$ eutectic has presented many unresolved problems.

\subsection{CONTAINMENT MATERIALS}

Thermochemical analyses were performed to estimate the chemical stablity of possible containment materlals with molten sillcon alloys and germanium at 1100 to $1400 \mathrm{~K}$. The analyses utllized FACT (Facility for the Analysis of Chemical Thermodynamics, McGill University) and identified alumina, graphite, sllicon carbide, and boron nitride as potentlal contalnment materlals at the respectlve melting points of the referenced PCMs.

Porosity of the containment materlals was considered. Low porosity and small pore size are necessary to limit the ingress of the molten PCMs into the walls. Such ingress can lead to mechanical fatigue of the contalnment materials from repeated liquid/solid transformation. Also, segrogation of alloy materials and, hence, loss of performance are possible. Low porosity graphite, chemically vapor deposited (CVD) silicon carblde, and CVD boron nitride meet tilese sriteria. In addition, to minimize the open porosity at the surface that contacis the molten PCMs, the surfaces of some graphite crucibles were coated with pyroilytically deposited carbon (PyC). Wetting of the container by the molten PCMs was also evaluated because wetting will ald the ingress of the molten PCMs into the walls of the container.

Finally, physical compatlbility is also an important consideration. The containment materials must have sufficient chanical strength or coefficients of thermal expansion to mitigate the effect of the volume changes of the PCMs from phase transformation and thermal expansion. The thermal expansion coefficients ${ }^{4}$ of a few materlals are presented in Fig. 1. It should be noted that the expansion of graphite varies over a wide range and can, at least in theory, be chosen approximately equal to that of germanium. Silicon carbide and boron nitride have expansions less than that of germanium. Thus, cooling of germanium to room temperature in these materlals can be accommodated. However, heating to the operating temperature with a solid, snug-fitting mass of germanium could result in failure of the container. On the other hand, alumina has thermal expansion greater than that of germanlum. Thus, cooling of germanium in this material should result in failure of the alumina container. However, because of the greater mechanical strength of alumina vs germanium, fallure did not occur.

Alumina was selected as the capsule materlal for compatibllity testing of the silicon alloys (except as noted in the following), while both graphite and alumina were used to contain germanium. Although it was predicted that graphite would react with the sllicon alloys to form silicon carbide, compatibility tests were performed nevertheless to evaluate whether the resultant sillcon carbide reaction product would act as a barrier to extensive attack. Alumina, graphite, pyrolytic carbon on graphitt, and CVD sllicon carbide and boron nitride were obtalned from commerclal sources. 


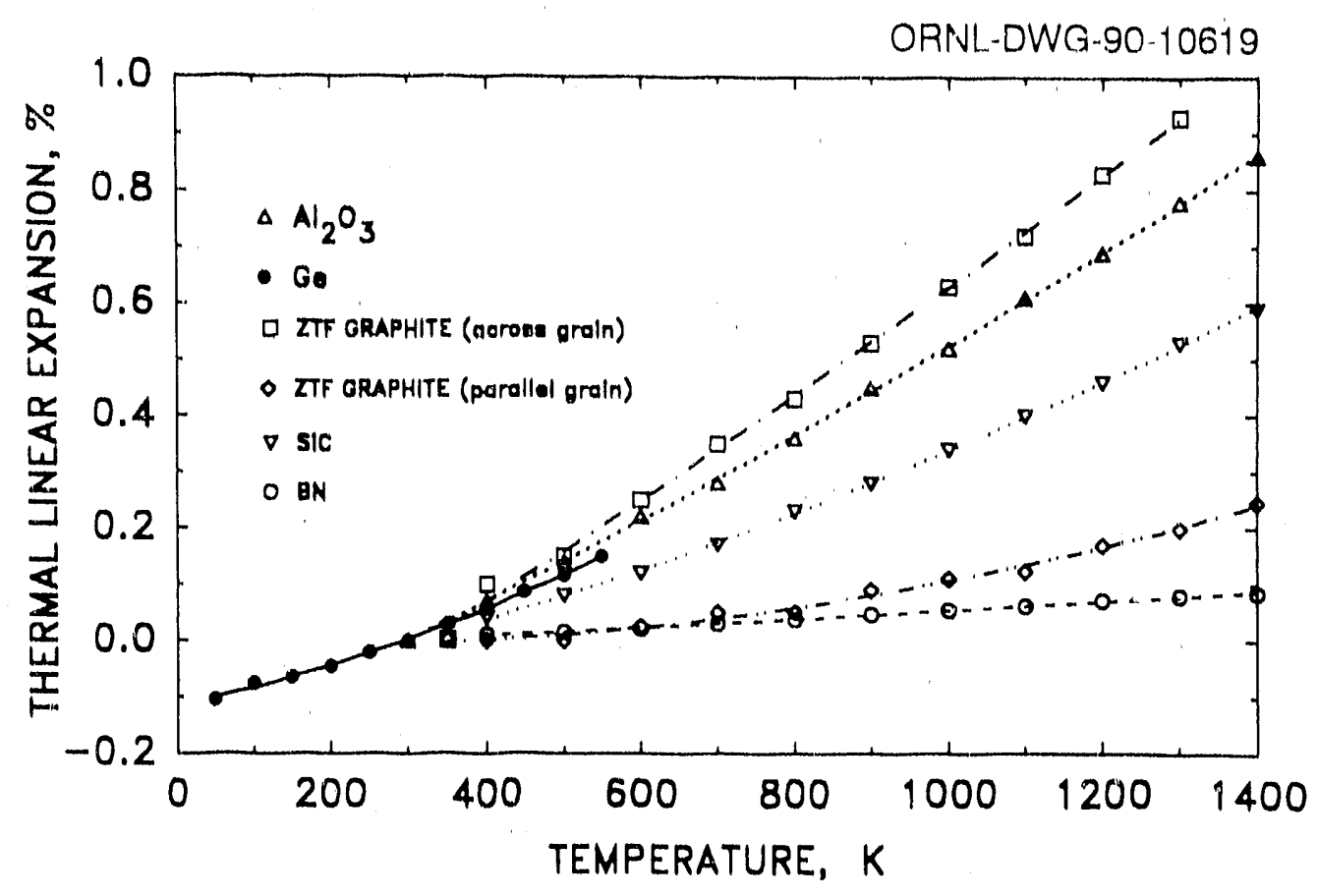

Fig. 1. Thermal expansion coeificients of germanium and selected containment materials.

\section{EXPERIMENTAL PROCE.DURES}

\subsection{PREPARATION OF NiSi-NiSi ${ }_{2}$ EUTECTIC ALLOY}

The appropriate amounts of nickel and silicon for $38 \mathrm{wt} \%$ sillicon were arc-melted and homogenized under an argon atmosphere. The molten alloy was drop-cast into a water-cooled copper mold under an argon atmosphere. Samples from three different positions along the length of the casting were evaluated using mass spectrometry, $X$-ray diffraction, and metallographic techniques.

\subsection{COMPATIBILITY TESTING}

Specimens of the candidate thermal storage material and the potential container material were placed in an "inert" alumina crucible (with cap). Alternatively, specimens of the thermal storage materials were placed in a cruclble (with cap) of the potential container materlal. The alumina or container material crucibles were, as shown in Fig. 2, encapsulated under vacuum $\left(10^{.1} \mathrm{mPa}\right)$ in quartz. The assembly was heated to $50 \mathrm{~K}$ above the melting point of the candidate storage material and maintalned at this temperature for $168 \mathrm{~h}$. Subsequent to exposure, the specimens were subjected to visual, metallographic, and scannirig electron microscoplc analyses. 
YP 6834

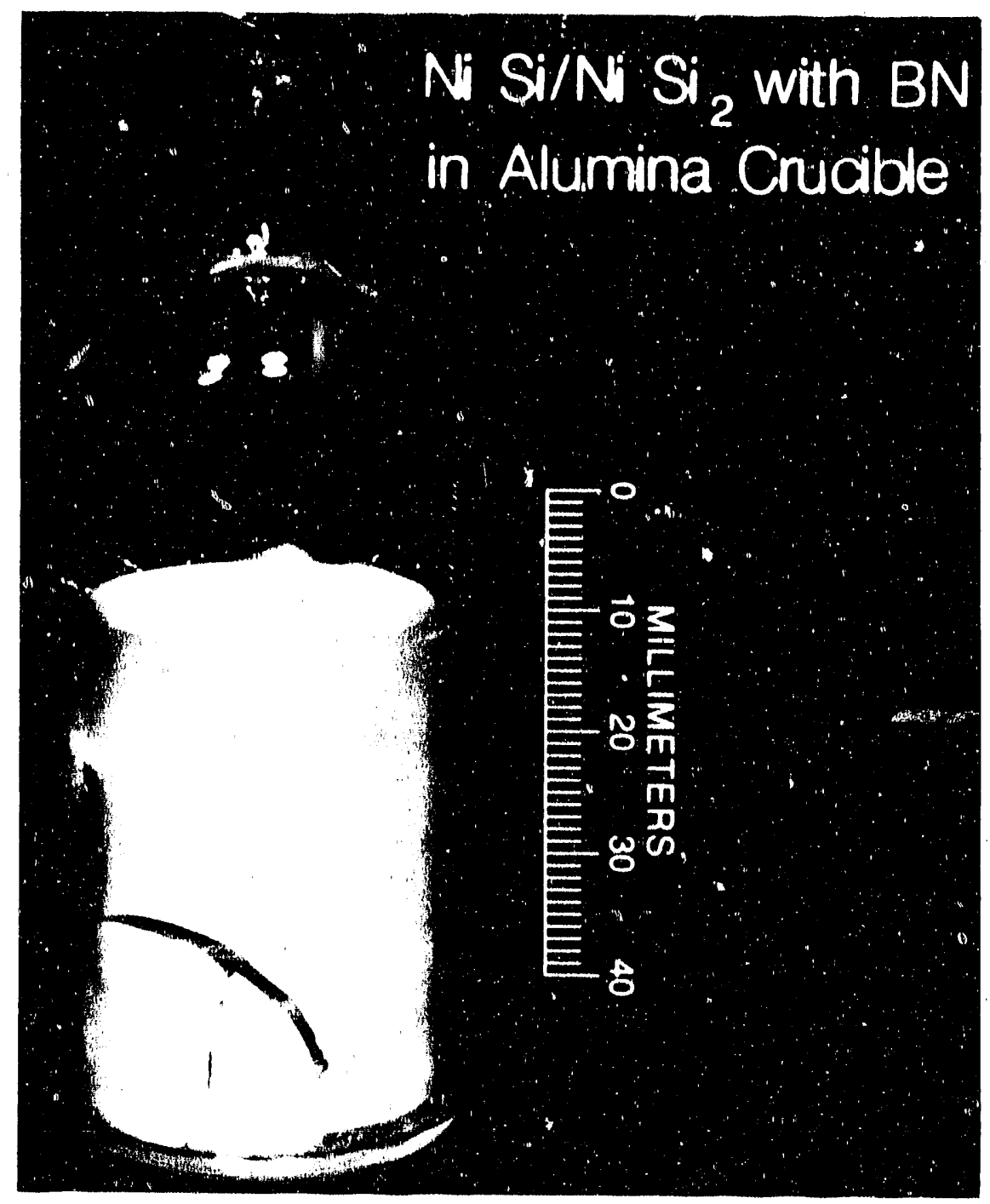

Fig. 2. Test assembly consisting of an alumina crucible and cap encapsulated in quartz. 


\section{RESULTS AND DISCUSSION}

\subsection{CHARACTIERIZATION OF NiSi-NiSi ${ }_{2}$ EUTECTIC ALLOY}

Chemical analysis for nickel and silicon in the NiSi-NiSi ${ }_{2}$ alloy was performed by mass spectromerry, and the normalized concentrations are presented in Table 4. The designations SD1, SD2, and SD3 refer to the top, middle, and bottom of the cast specimen, respectively. The targeted composition was $38 \mathrm{wt} \%$ silicon. As is shown, there was some variation in composition through the length of the casting, and the average silicon content was higher than the targeted concentration. However, the composition was ivell within the $\mathrm{NiSi}-\mathrm{NiSi}_{2}$ two-phase field and had a melting point quite close to that of the eutectic.

Optical micrographs of specimen SD4 from the mid-section of the casting are shown in Figs. 3 and 4 . The specimen was metallographically prepared and etched with $50 \% \mathrm{HCl} / 10 \%$ Gly $/ 10 \% \mathrm{HNO}_{3}$. A typical eutectic structure is evident with a slight excess of the $\mathrm{NiSi}_{2}$ phasie. Comparing Fig. 3 to Fig. 4 , it is seen that the distribution of this excess phase is not uniform and, in places, quite small. The cracks suggest severe stress generation during solidification and cooling.

The results of the X-ray diffraction analysis confirm the presence of both the $\mathrm{NiSi}_{2}$ and NiSi phases. Those phases are also indicated by the phase diagram. ${ }^{5}$ However, certain features of the X-ray diffraction pattern warrant further discussion. A segment of the diffraction paltern produced using copper $k$-alpha radiation of wavelength $1.54059 \AA$ is shown in Fig. 5. The diffraction peaks corresponding to $\mathrm{NiSi}_{2}$ were well defined. The average value of the lattice parameter calculated from the identified lattice planes is $5.396 \pm 0.008 \AA$. In fact, the (333) and (440) reflections gave a lattice parameter of $5.400 \AA$. That is to be compared to $5.406 \AA$ for $\mathrm{NiSi}_{2}\left(48.90 \mathrm{wt} \%\right.$ silicon) ${ }^{5}$ with a $\mathrm{CaF}_{2}(\mathrm{C} 1)$ type structure. The remaining diffraction peaks were quite broad. This broadening render's the analysis more difficult and ambiguous. In this case, the lattice parameter values of $a=5.62 \AA, b=5.18 \AA, c=3.34 \AA$ for orthorhombic NiSi $(32.37$ wt $\%$ silicon $)^{5}$ were used to calculate the diffraction angles. Comparisons were made with the broad peak positions. There was good agreement between the centroids of the broad peaks and the calculated diffraction angles. The broadening could be a result of stresses generated during casting of this material, a third phase, or a range of stoichiometry for $\mathrm{NiSi}$. However, such a range is not indicated in the phase diagram, ${ }^{5}$ and stresses may have only affected the NiSi diffraction peaks. Thus, the presence of a third phase could not be absolutely ruled out.

Table 4. Spectrographic analysis of $\mathrm{NiSi}-\mathrm{NiSi}_{2}$ eutectic alloy

\begin{tabular}{llll}
\hline \multirow{2}{*}{$\begin{array}{l}\text { Element } \\
\text { (wt \%) }\end{array}$} & \multicolumn{3}{c}{ Specimen } \\
\cline { 2 - 4 } & SD1 & SD2 & SD3 \\
\hline $\mathrm{Si}$ & 40.9 & 44.5 & 42.3 \\
$\mathrm{Ni}$ & 59.1 & 55.5 & 57.7 \\
\hline
\end{tabular}


送
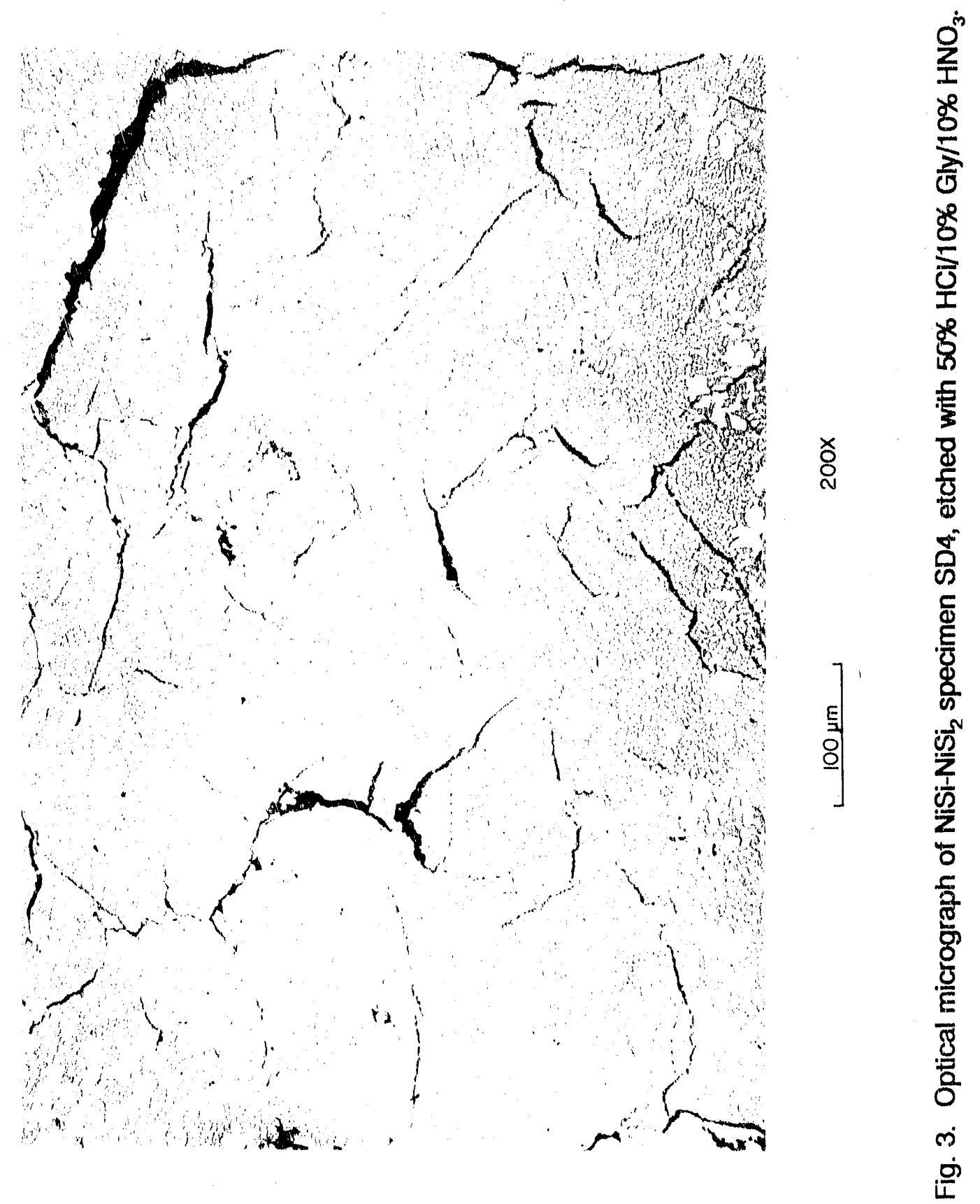

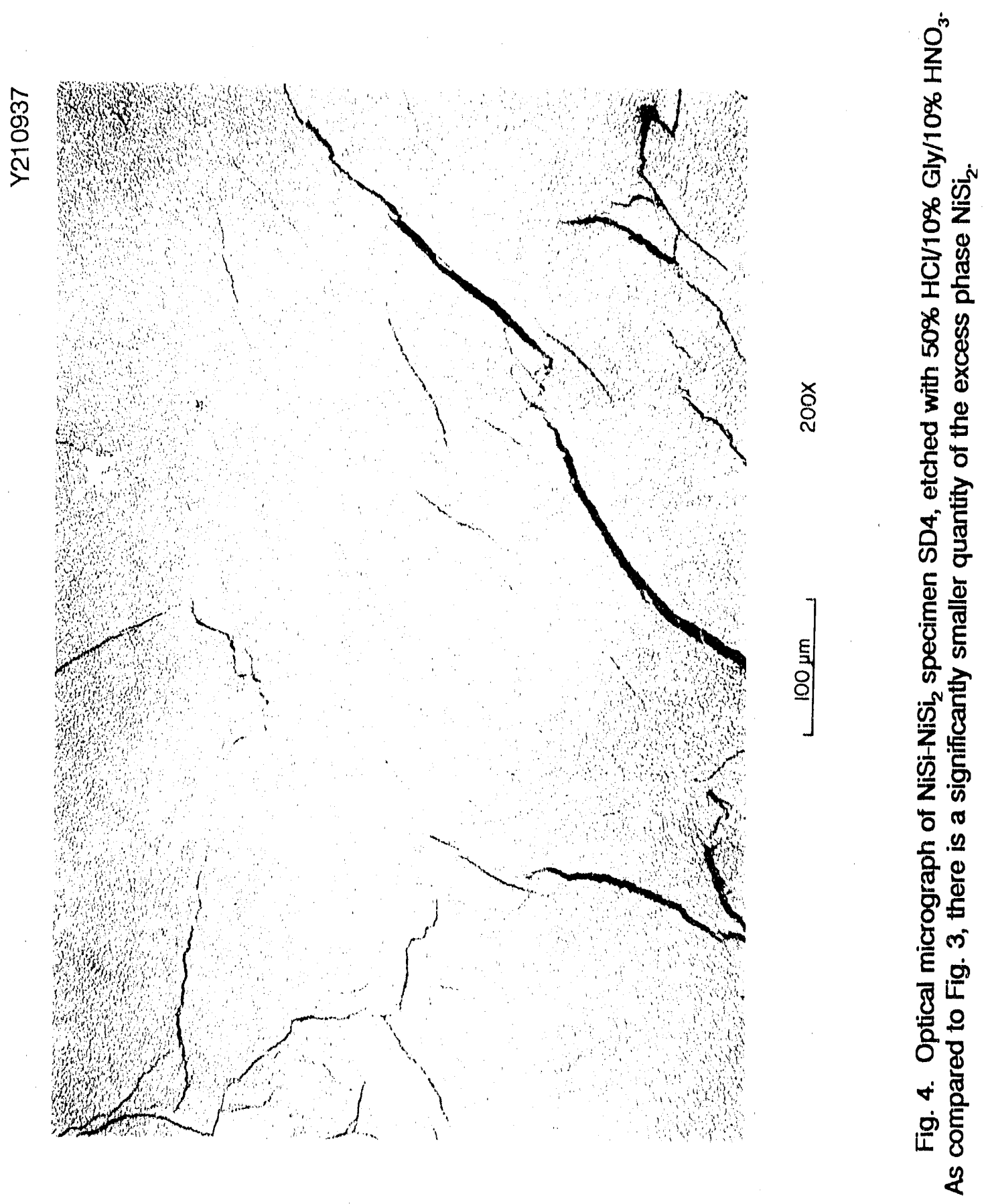
ORNL-DWG-90-10620

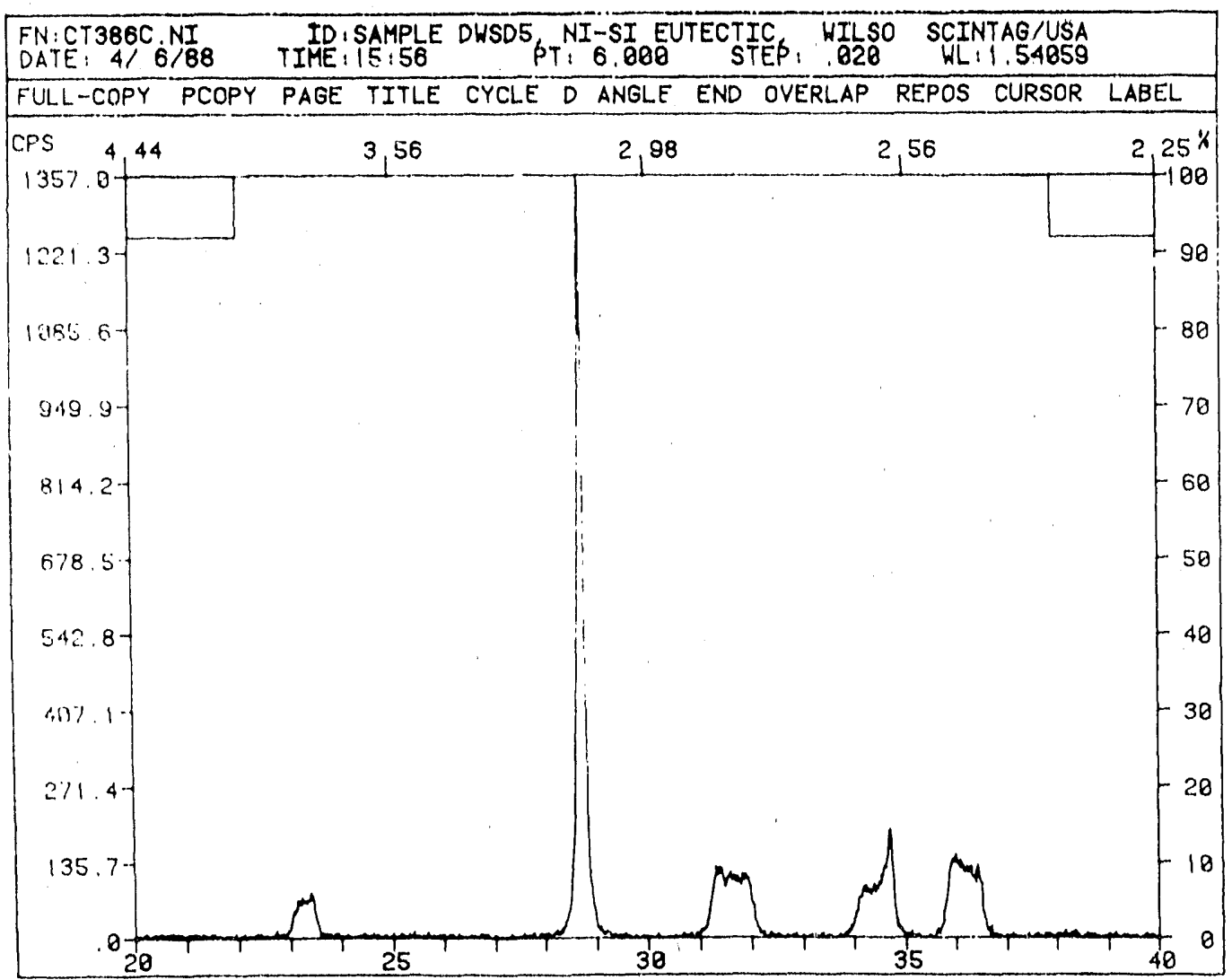

Fig. 5. Segment of $\mathrm{X}$-ray diffraction pattern of $\mathrm{NiSi}-\mathrm{NiSi}_{2}$ eutectic, using copper $k$-alpha radiation of wavelength $1.54059 \AA$. 


\subsection{COMPATIBILITY STUDIES WITH NISI-NiSi ${ }_{2}$ EUTECTIC ALOY}

Exposures of $\mathrm{NiSi}-\mathrm{NiSi}$, eutectic alloy to pyrolytic carbon on graphite, alumina, and CVD silicon carbide and CVD boron nitricle in alumina crucibles were performed at $1289 \mathrm{~K}$. In all cases, on completion of the experiments, it was found that the crucibles had broken. However, the NiSi-NiSl${ }_{2}$ ingot was totally retained within the crucible and appeared to have begun solidifying with the crucible still intact (see Fig. 2). Neither the coefficient of thermal expansion nor the volume change (expansion) on freezing of $\mathrm{NiSl}-\mathrm{NiSi}_{2}$ is known. Therefore, it can only be speculated whether fallure occurred at the liquid-to-solid transformation or after further cooling. Initial metallographic results of these short-term isothermal screening tests of pyrolytic carbon, CVD sillicon carbide, and CVD boron nitride appear favorable from a chemical compatibility perspective.

An optical micrograph of NiSi-NiSi ${ }_{2}$ tested at $1289 \mathrm{~K}$ for $168 \mathrm{~h}$ in a crucible of pyrolytic carbon of thickness $0.005 \mathrm{~cm}(0.0020 \mathrm{in}$.) on graphite is shown in Fig. 6 . Note that there is a very thin layer of the pyrolytic carbon attached to the alloy with little evidence of reaction for this isothermal short-term experiment. An SEM micrograph of a portion of the pyrolytic carbon on graphite near a fracture site of the crucible is shown in Fig. 7. This surface was in contact with molten NiSi-NiSl${ }_{2}$ at temperature. Note there are indications that the pyrolytic carbon has been pulled away from part of the graphite surface. Energy-dispersive X-ray (EDX) analysis indicated that there were more nickel and silicon on the pyrolytic carion surface than on the graphite surface. However, this analysis was complicated by the presence of "foreign" elements such as alumina, iron, calcium, and silicon in the graphite.

As shown in Fig. 8, a negative meniscus was observed with CVD silicon carbide. This indicates a nonwetting system. An SEM EDX examination of the $\mathrm{NiSi}-\mathrm{NiSl}_{2} / \mathrm{SiC}$ interface indicated that one small area of the CVD silicon carbide was wetted by the $\mathrm{NiSi}-\mathrm{NiSi}_{2}$ eutectic alloy at the test temperature. This specimen was sectioned, and the area of interest was prepared for metallographic examination. Currently, nothing unique has been observed in that area. Also, the EDX analysis indicated that a quite small quantity of alumina was on the surrounding surface of the NiSi-NiSl 2 alloy. The quantity appears to result from a dusting of alumina.

In Fig. 9, strips of CVD boron nitride contained within $\mathrm{NiSi}-\mathrm{NiSl}_{2}$ and germanium after compatibility testing are shown. Note that the $\mathrm{NiSi}-\mathrm{NiSi}_{2}$ eutectic alloy has shattered the alumina crucible (and is in one plece), while the germanium did not. A metallurgical examination of the $\mathrm{NiSi}-\mathrm{NiSi}_{2} / \mathrm{CVD}$ boron nitride interface indicated good chemical compatibility and no migration of the PCM into the boron nitride. An optical micrograph of the section is shown in Fig. 10.

\section{COMPATIBILTYY STUDIES WITH GERMANIUM}

The short-term exposures ( $168 \mathrm{~h}$ at $1283 \mathrm{~K}$ ) of germanium to graphite, PyC, CVD silicon carbide, and CVD boron nitride all indicated good compatibility. There were no detectible chemical reactions and no migration of the germanium into the test containment materials. There was adequate physical compatibility with graphite and alumina as all the capsules remained intact on cooling to room temperature (see for example, Fig. 9). However, as Lauf ${ }^{6}$ has demonstrated, depeniding on the grade of graphite, there can be seepage of germanium through the walls during thermal cycling. Seepage occurred with Stackpole graphite but not with Poco graphite. Further, modeling 
$\frac{6}{6}$
$\infty$
2
2

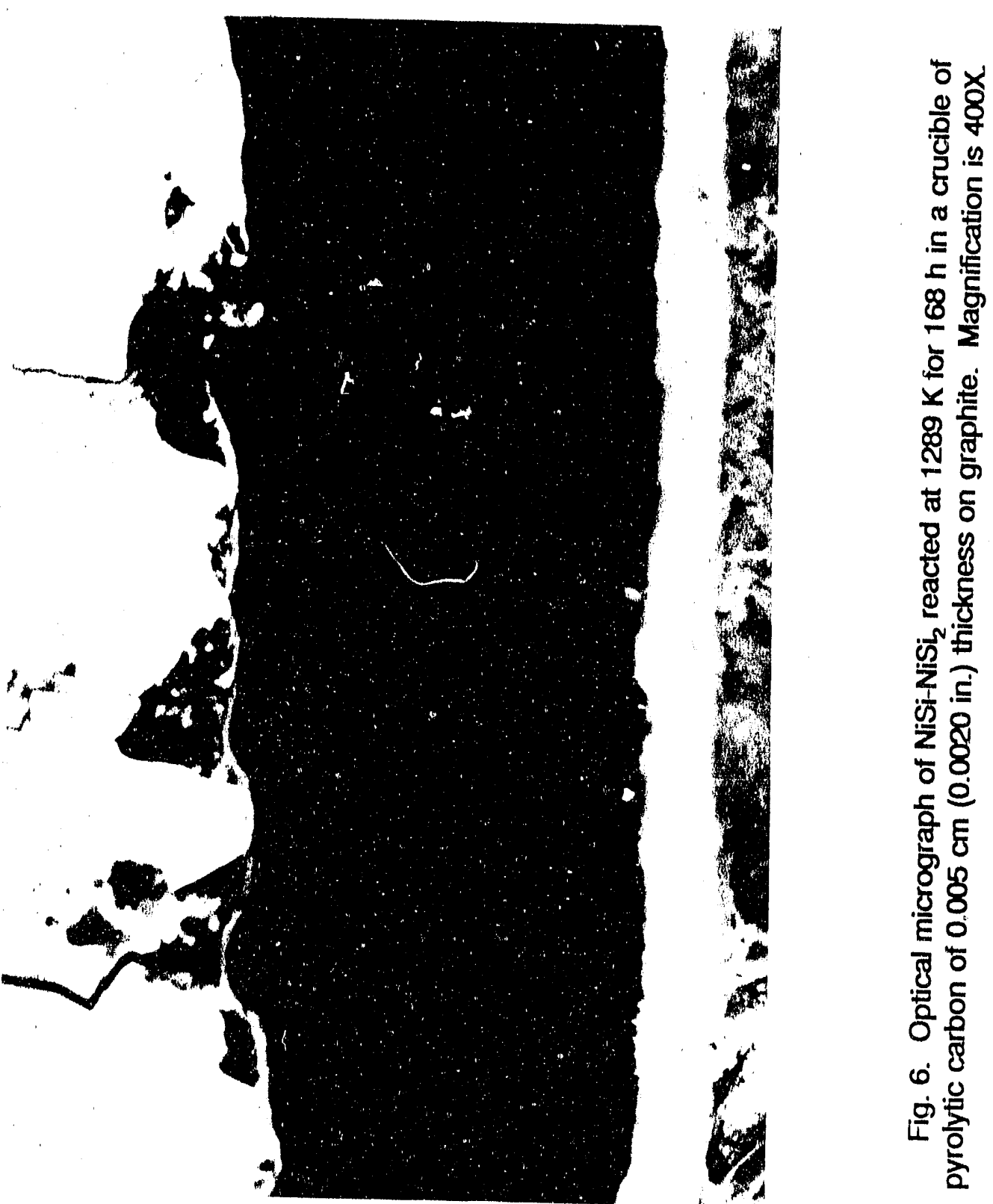




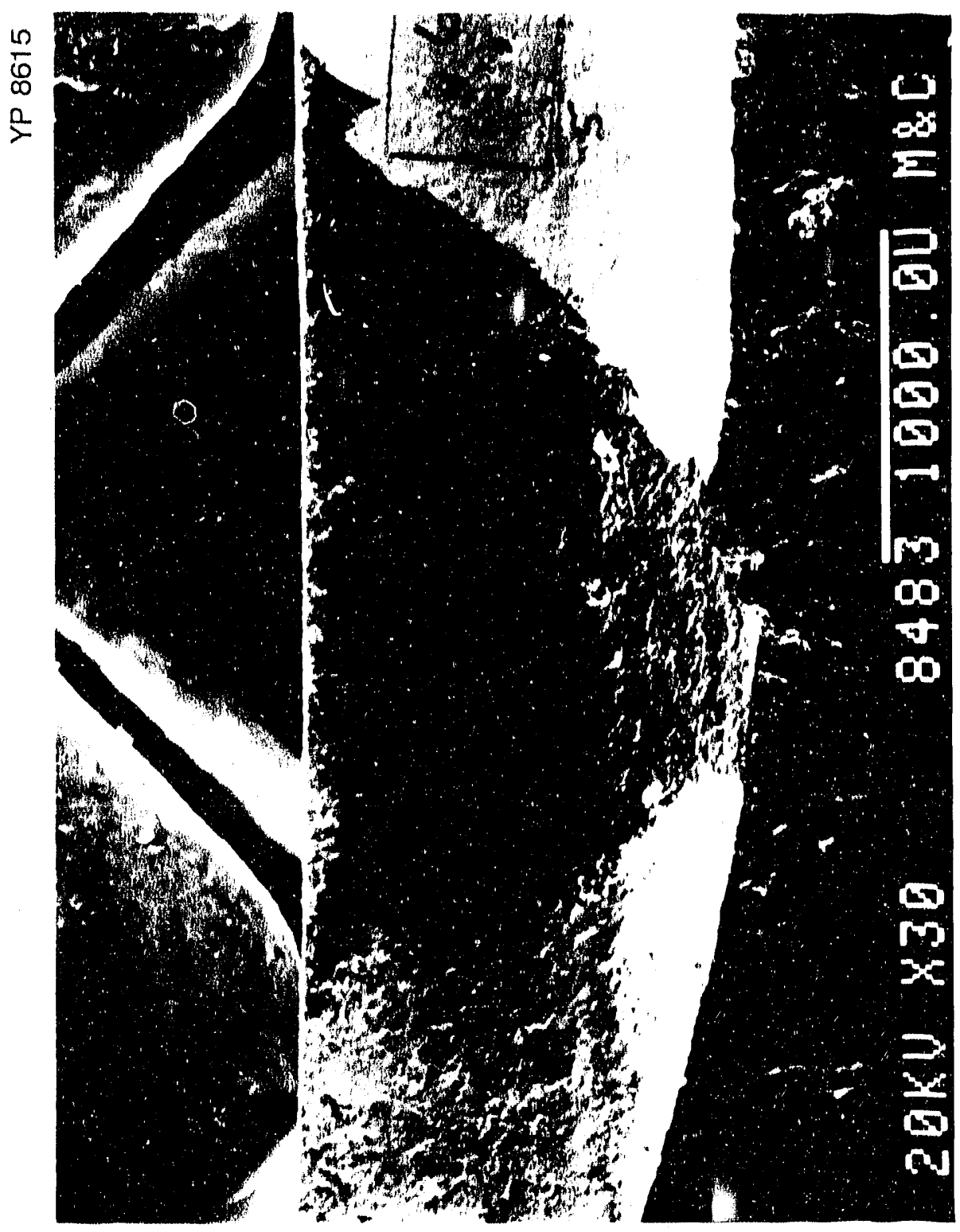

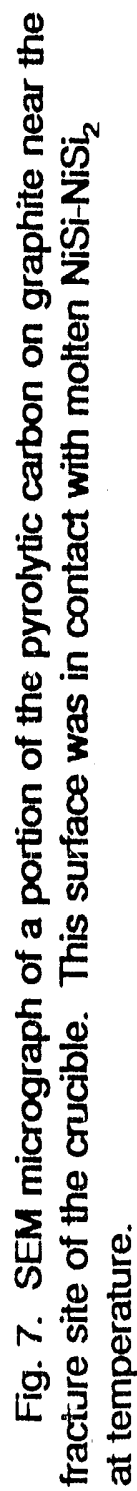


\%
/
0
$ㅁ$

亡̊丿

สั

8

胥

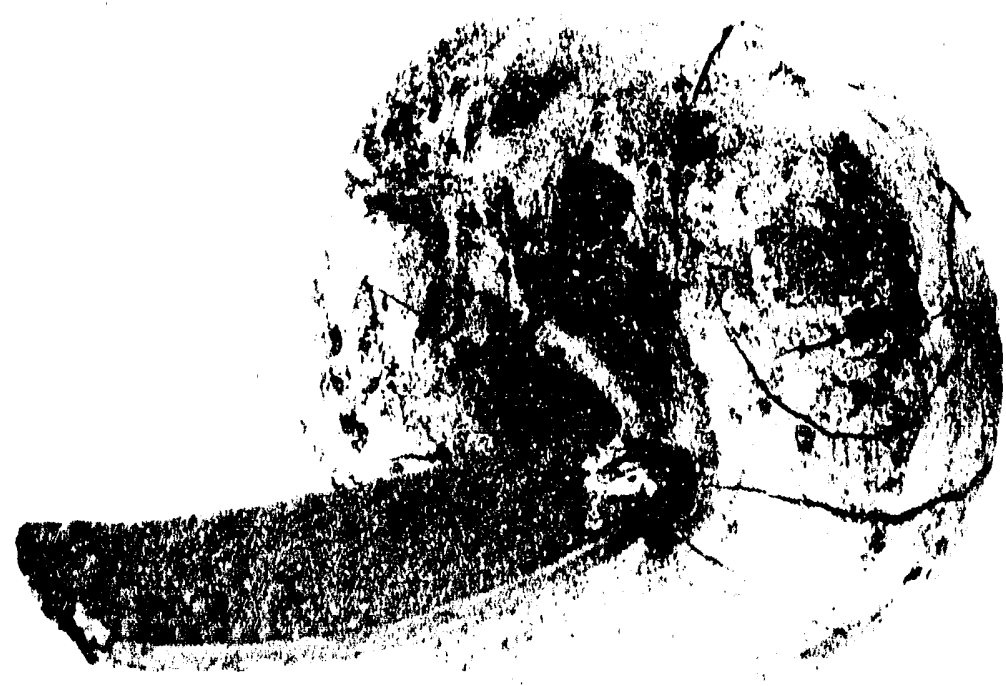

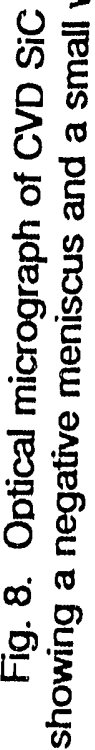



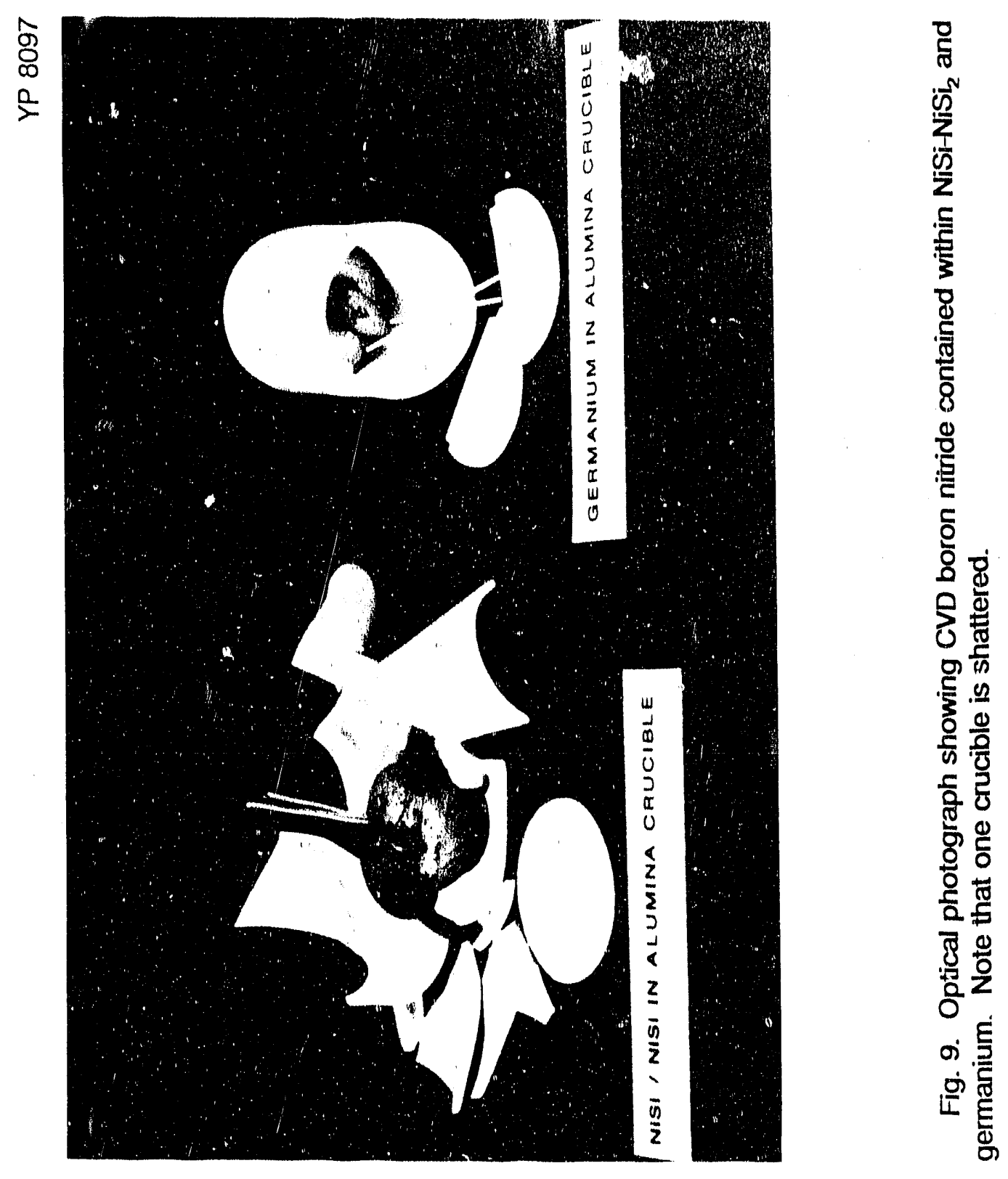


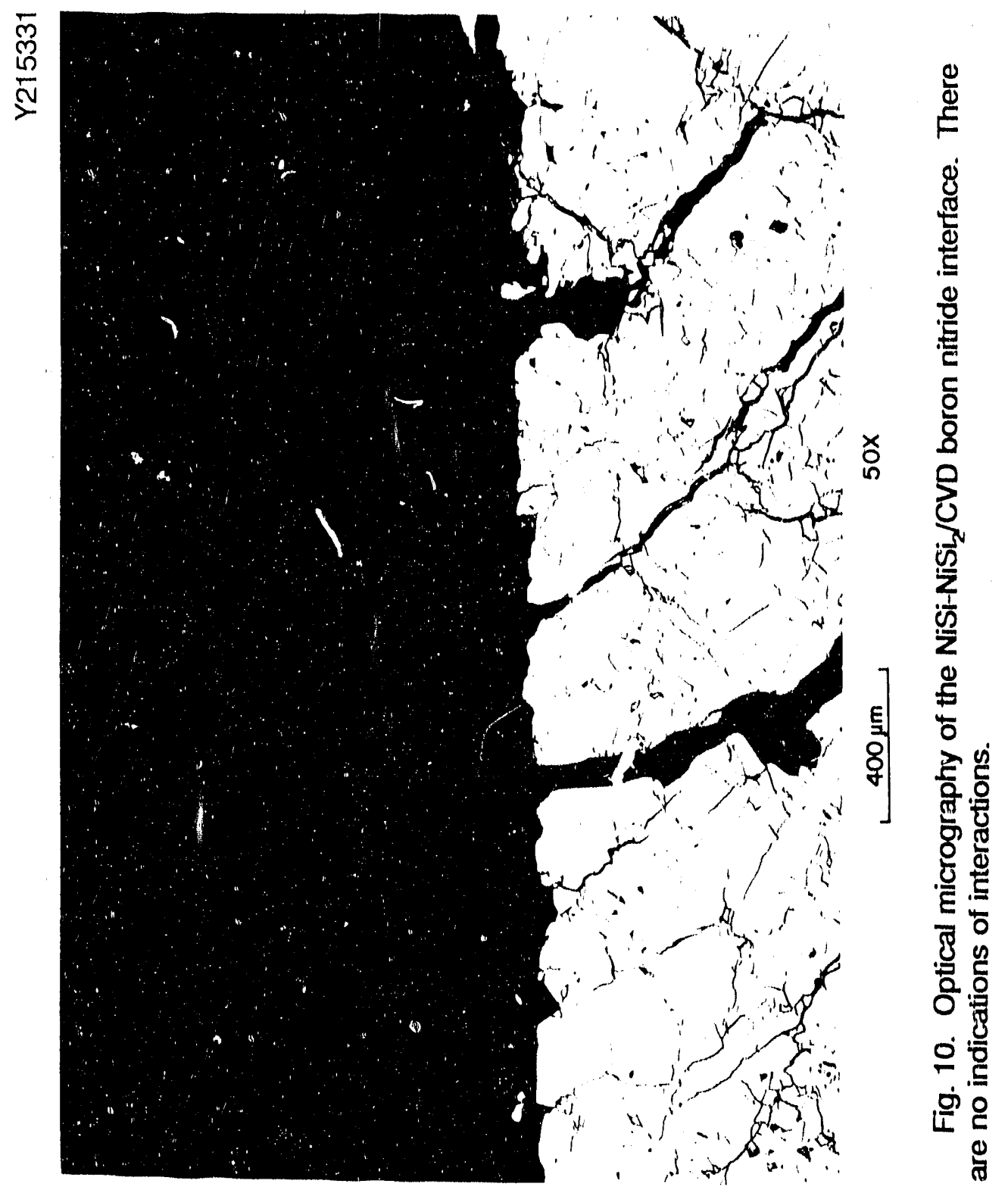


work on thermal performance of heat recelver concepts using germanium as the metallic $\mathrm{PCM}^{7}$ has shown virtual elimination of orbit-associated temperature variations in the storage systems.

\section{$4.4 \mathrm{Mg}_{2} \mathrm{SI}$-SI EUTECTIC ALLOY}

The approprlate amounts of $\mathrm{Mg}_{2} \mathrm{SI}$ and SI for 57 to $58 \mathrm{wt} \%$ silicon combined in an alumina crucible (with cap). The crucible, in turn, was encapsulated under vacuum $\left(10^{-1} \mathrm{mPa}\right.$ ) in quartz. The assembly was heated to $1423 \mathrm{~K}$ and allowed to furnace cool. After cooldown the quartz envelope was found shattered. There were no Indications of alloying. There are questions as to the usefulness of Itils eutectic alloy for use in thermal energy storage systems because of the high vapor pressure assoclated with $\mathrm{Mg}_{2} \mathrm{Sl}$.

\section{SUMMARY}

The study of the compatibillty of containment materlals with metal-based PCM involved considering chemical reactivity; solubillty; and physical compatibility, especially thiermal expansion mismatch.

Thermochemical analyses were performed to estimate the chemical stabillty of possible containment materlals with molten silicon alloys and germanlum at 1100 to $1400 \mathrm{~K}$. The analyses utilized FACT and identifled alumina, graphite, sillcon carblde, and boron nitride as potential containment materials at the respective melting points of the referenced PCMs.

Graphite was confirmed experlmentally under short-term isothermal conditions to be a good containment materlal for germanium. Confirmation under cycllc conditions has been demonstrated. ${ }^{6}$ Germanium contained within graphilte has proven to be a viable TES system. Furthermore, it has been demonstrated recently that this system virtually eliminates orbit-assoclated temperature variatlons in the storage systems. The Initial phase of this work has also demonstrated that germanlum is cumpatible with pyrolytio carbon, CVD silicon carbide and CVD boron nitride.

It has been demonstrated that NiSi-NISI 2 can be readily produced and qualified.

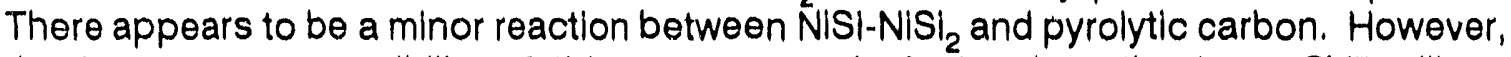
the long-term compatibility of this system needs further investigation. CVD sillicon carbide and CVD boron nitride also appear promising for containment of $\mathrm{NISI}-\mathrm{NISI}_{2}$ from chemical compatiblity considerations.

\section{ACKNOWLEDGMENTS}

The authors thank O. B. Cavin for X-ray diffraction analysis; J. R. Mayotte for metallography; R. R. Leedy for SEM; C. L. Angel and R. L. Freeny for photography; and H. D. Neu for preparation of the final manuscript. 


\section{REFERENCES}

1. Faget, N. M., Fraser, W. M., and SImon, W. E., "Thermal Energy Storage for a Space Solar Dynamlo Power System," pp. 2.378-2.383 in Proceedings of the 20th Intersociety Energy Conversion Engirieering Conference, SAE P-164, Vol. 2, Soclety of Automotive Engineers, Inc., Warrendale, Pa., August 1985.

2. Downing, R. S., and Parekh, M. B., "Thermal Energy Storage for an Organic Rankine Cycle Solar Dynamic Space Powered Station," pp. 2.397-2.409 In Proceedings of the 20th Intersociety Energy Conversion Engineering Conference, SAE P-164, Vol. 2, Soclety of Automotive Engineers, Inc., Warrendale, Pa., August 1985.

3. Solomon, A. D., "A Numerlcal Study of the Performance of Latent Heat Storage for Solar Dynamic Power Systems," pp. 2.393-2.396 In Proceedings of the 20th Intersociety Energy Conversion Engineering Conference, SAEP -164, Vol. 2, Soclety of Automotlve Englneers, Inc., Warrendale, Pa., August 1985.

4. Touloukian, Y. $S_{1,}$ ed, Thermophysical Properties of High Temperature Solid Materlals, Macmillan, Now York, 1967, Vol. 1, pp. 315 and 526 ; Vol. 4, p. 22; Vol. 5, pp. 129 and 507.

5. Hansen, M., pp. 1039-1042 in Constitution of Binary A.loys, 2nd ed., McGraw Hill, Now York, 1958.

6. Lauf, R. J., and Hamby, C., Metallic Phase-Change Materials for Solar Dynamic Energy Storage Systems, ORNL/TM-11351, Martin Marietta Energy Systems, Inc, Oak Rldge Natl. Lab., to be published.

7. Crane, R. A., and Bharadhwaj, "Thermal Performance of Speciflc Heat Receiver Concepts for Advance Solar Dynamic Appllcations," pp. 943-951 in Proceedings of the 24th Intersociety Energy Conversion Engineering Conference, Vol. 2, Institute of Electrical and Electronics Engineers, New York, August 1989. 

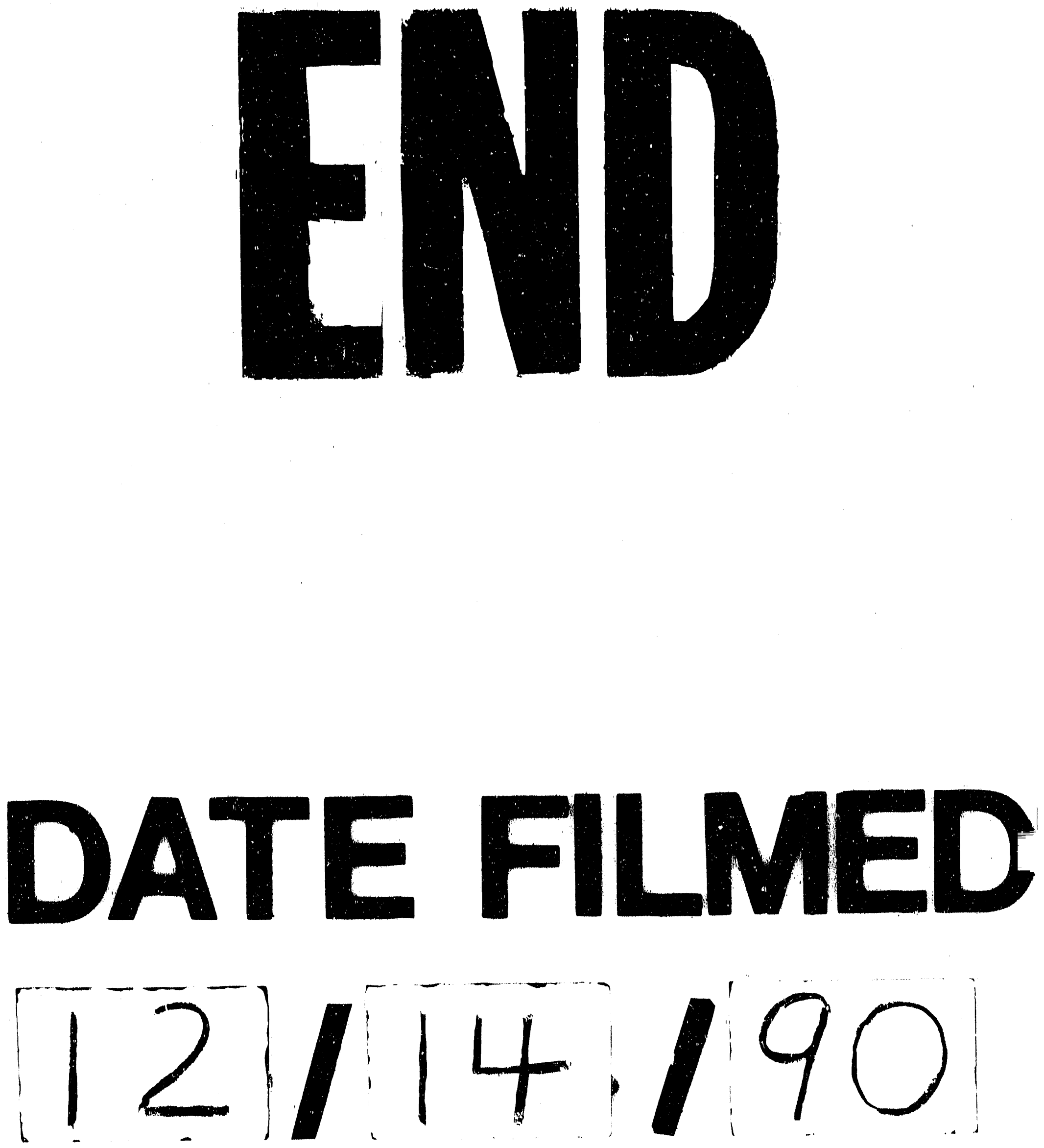
